\title{
DOES THE EDGE EFFECT INFLUENCE PLANT COMMUNITY STRUCTURE IN A TROPICAL DRY FOREST ${ }^{1}$
}

Diogo Gallo Oliveira ${ }^{2}$, Ana Paula do Nascimento Prata ${ }^{3}$, Leandro Sousa Souto ${ }^{4}$ e Robério Anastácio Ferreira $^{2}$

\begin{abstract}
Edge effects are considered a key factor in regulating the structure of plant communities in different ecosystems. However, regardless to few studies, edge influence does not seem to be decisive in semiarid regions such as the Brazilian tropical dry forest known as Caatinga but this issue remains inconclusive. The present study tests the null hypothesis that the plant community of shrubs and trees does not change in its structure due to edge effects. Twenty-four plots $(20 \times 20 \mathrm{~m})$ were set up in a fragment of Caatinga, in which 12 plots were in the forest edges and 12 plots were inside the fragment. Tree richness, abundance and species composition did not differ between edge and interior plots. The results of this study are in agreement with the pattern previously found for semiarid environments and contrasts with previous results obtained in different environments such as Rainforests, Savanna and Forest of Araucaria, which indicate abrupt differences between the border and interior of the plant communities in these ecosystems, and suggest that the community of woody plants of the Caatinga is not ecologically affected by the presence of edges.
\end{abstract}

Key words: Plant diversity, Semiarid environments, Fragmentation, Ecotones.

\section{O EFEITO DE BORDA INFLUENCIA A ESTRUTURA DA COMUNIDADE VEGETAL EM UMA FLORESTA TROPICAL SECA?}

\begin{abstract}
RESUMO-Efeitos de borda são considerados fator-chave na regulação da estrutura de comunidades vegetais em diferentes ecossistemas. Entretanto, apesar dos poucos estudos relacionados, o efeito de borda parece não ser determinante em regiões semiáridas, como a floresta tropical seca brasileira, conhecida como Caatinga. Este estudo testou a hipótese nula de que a comunidade vegetal arbustivo-arbórea não sofre alterações em sua estrutura, riqueza e composição devido ao efeito de borda. Foram instaladas 24 parcelas $(20 \times 20 \mathrm{~m})$ em um fragmento de Caatinga arbórea, sendo 12 parcelas na borda do fragmento e 12 parcelas no seu interior. A riqueza, abundância e composição das espécies não diferiram estatisticamente entre as parcelas de borda e interior. Os resultados deste estudo corroboram um possível padrão de ambientes semiáridos e contrastam com resultados anteriores de diferentes ambientes, como florestas tropicais úmidas, cerrado e floresta de araucária. Indicam diferenças abruptas entre comunidades vegetais da borda e do interior de fragmentos florestais, sugerindo que a comunidade arbustivo-arbórea da Caatinga não é ecologicamente afetada pela presença de bordas.
\end{abstract}

Palavras-chave: Diversidade, Ambiente semiárido, Fragmentação, Ecótono.

\footnotetext{
${ }^{1}$ Recebido em 11.11.2012 aceito para publicação em 17.01.2013.

${ }^{2}$ Departamento de Ciências Florestais. Universidade Federal de Sergipe, UFS, Brasil. E-mail:<diogo_gallo@ hotmail.com>, <roberioaf@yahoo.com.br>.

${ }^{3}$ Departamento de Biologia, Universidade Federal de Sergipe, UFS, Brasil. E-mail:<apprata@yahoo.com.br>.

${ }^{4}$ Núcleo de Ecologia, Universidade Federal de Sergipe, UFS, Brasil. E-mail:<leandrosouto@ufs.br>.
} 


\section{INTRODUCTION}

The fragmentation of contiguous areas transforms the landscape into a mosaic of small patches, isolated by a matrix of the non-original habitat (FAHRIG, 2003), leading to physical and biological changes as a result of habitat loss and insularization (TABARELLI et al., 1999).

In these fragmented landscapes, populations of forest species are reduced and the migration and dispersal patterns are disrupted. Thus, the previously isolated habitats become exposed to external conditions, resulting in a gradual erosion of biological diversity (TILMAN et al., 1994). A consequence of this process is the increase of edge effects, which is generated by the contact with the surrounding matrix, representing an important aspect of structural changes in plant communities (MURCIA, 1995).

For various ecosystems, the borders between fragmented habitats are often ecologically different from the interior of the patches, and to find out how ecological patterns change near the edges is the key to understanding the dynamics of the impacts of fragmentation on plant communities (MARCHAND; HOULE, 2006; RIES et al., 2004) since the creation of abrupt edges in the forest may severely modify local microclimatic conditions, increase tree mortality, and promote the establishment of invasive species (TILMAN et al., 1994).

Microclimatic conditions at the edges are usually different from the interior, reaching higher values of air and soil temperature, wind speed, and lower air relative humidity and soil moisture (CAMARGO; KAPOS, 1995; DIDHAM; LAWTON, 1999). Such alterations may change the diversity, composition, structure and dynamics of plant communities in these forest fragments (SAMPAIO; SCARIOT, 2011).

Several studies have attempted to understand how edge effects, as well as other parameters of landscape structure, influence the quality of habitat. However, most studies on these effects was performed in humid tropical forests, mainly in the Atlantic Forest complex (PACIENCIA; PRADO, 2004; SANTOS et al., 2008; SILVA et al., 2011) and Amazonia (CAMARGO; KAPOS, 1995; LAURANCE et al., 1998; LAURANCE et al., 2001; MESQUITA et al., 1999; NASCIMENTO; LAURANCE, 2006). These studies showed that there was some kind of edge influence on at least one variable (i.e. tree abundance, species richness). For example, Ries et

Revista Árvore, Viçosa-MG, v.37, n.2, p.311-320, 2013 al. (2004), reviewed several studies and concluded that most of them indicated a neutral or positive relationship between the edge effect and the richness, diversity and abundance of plant species. However, the results found for humid forests cannot be directly applicable in tropical dry forests (TDFs), such as the Caatinga (SAMPAIO; SCARIOT, 2011).

Similar studies in semiarid environments are scarce. Few studies were done in areas of shrubby Caatinga (CAVALCANTI; RODAL, 2010; SANTOS; SANTOS, 2008) in a deciduous dry forest (SAMPAIO; SCARIOT, 2011) and in a semiarid Chaco in Argentina (CASENAVE et al., 1995). These studies suggest inconclusive results, because they demonstrated that the edge effect was only superficial (CAVALCANTI; RODAL, 2010) or did not cause significant changes in plant physiognomy, indicating that there is no edge influence in fragments of Caatinga and TDFs (SAMPAIO; SCARIOT, 2011; SANTOS; SANTOS, 2008). If there are no edge effects in dry forests, this pattern could be best observed in a fragment of primary forest, with a long time of isolation and higher abundance and richness of high trees.

The present study tests the hypothesis that the edge effect does not affect plant community structure in a fragment of arboreal Caatinga in order to contribute to the studies in fragmented areas, especially in TDFs ecosystems in northeastern Brazil.

\section{MATERIALS AND METHODS}

\subsection{Study area}

The study was conducted in a fragment of Caatinga in the state of Sergipe ( $10^{\circ} 01^{\prime}$ ' $45^{\prime \prime}$ ' and $10^{\circ} 02$ ' $18^{\prime \prime} \mathrm{S}$ and $37^{\circ} 24^{\prime} 57^{\prime \prime}$ and $\left.37^{\circ} 24^{\prime} 19^{\prime \prime} \mathrm{W}\right)$. The fragment has a total area of 50 ha and average elevation of $168 \mathrm{~m}$ (Figure 1). The study area is part of the São Francisco River basin in the far northern state of Sergipe.

The climate is classified as Tropical Semiarid - Bsh (Köppen), with average annual rainfall of $550 \mathrm{~mm}$ with the rainy season from March to July and the dry season lasting from seven to eight months. The average annual temperature reaches $26^{\circ} \mathrm{C}$. The relief is formed by geomorphologic "Pediplanos Sertanejos" and the predominant soil is classified as Eutrophic Litholic Neosol, according to the Brazilian System of Soil Classification (EMBRAPA, 2006). 


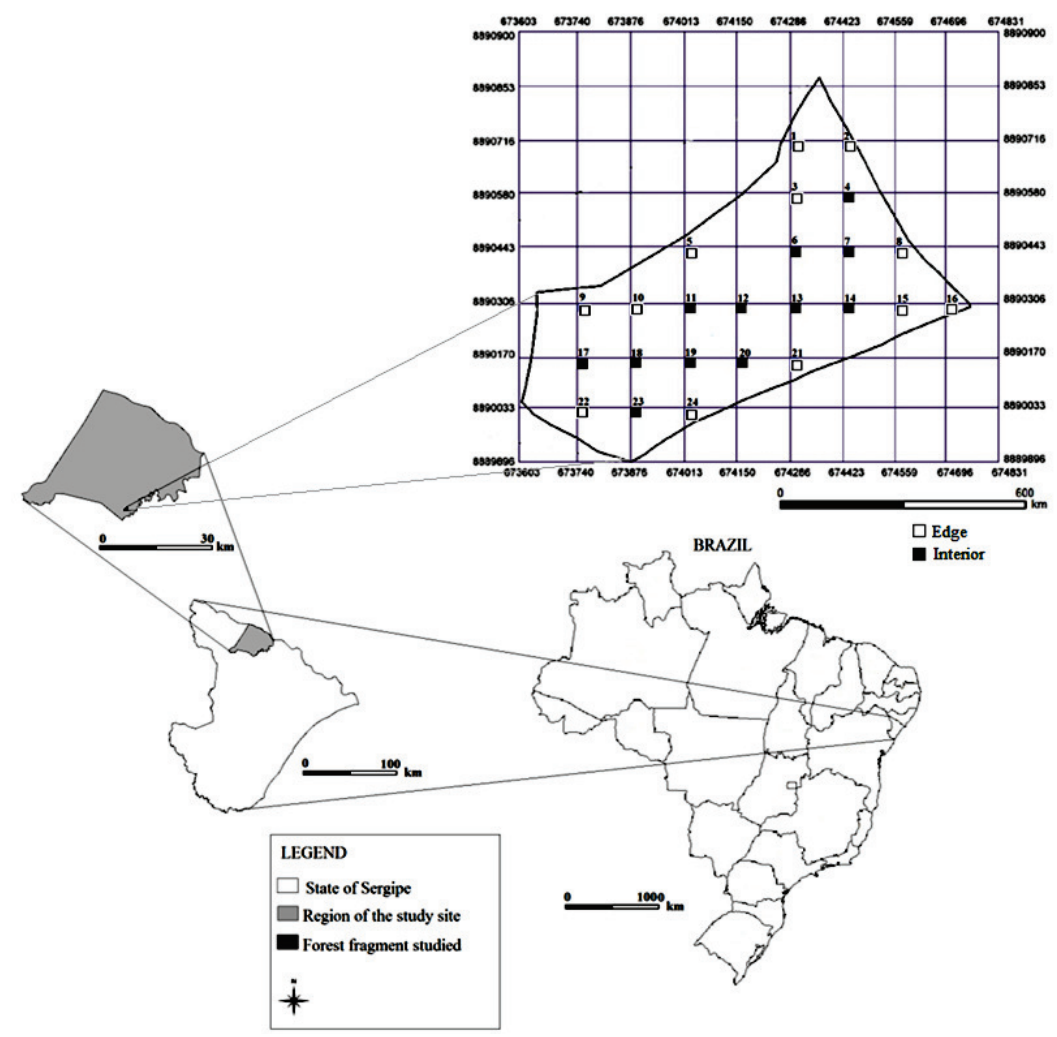

Figure 1 - Location of the study area in a Caatinga dry forest in the state of Sergipe, northeastern Brazil. Figura 1 - Localização da área estudada em uma floresta seca, Sergipe, nordeste do Brasil.

The vegetation type found in the study area match the physiognomic forms of Caatinga vegetation, which range from seasonally tropical dry forest (sensu ANDRADE-LIMA, 1981; PENNINGTON et al., 2000) to scrub vegetation (SAMPAIO, 1995). The physiognomy is marked by trees of the genus Anadenanthera, Aspidosperma, Poincianella and Myracrodruon (Caatinga types 1, 2 and 3 sensu ANDRADE-LIMA, 1981), and shrubs of the genus Bauhinia, Croton, Manihot and Maytenus. The vegetation height varies from 1.6 to $17.0 \mathrm{~m}$ with an average of $5.9 \pm 2.1 \mathrm{~m}$. The leguminous shrub and tree Bauhinia cheilantha (Bong.) Steud is the most abundant species in the study area.

The matrix surrounding the edges of the fragment is characterized for the most part by pasture. Remaining matrix is formed by open shrubland with species such as Croton sonderianus Müll. Arg. and Poincianella pyramidalis (Tul.) L. P. Queiroz, highly branched and height ranging from 2.0 to $2.5 \mathrm{~m}$, which are influenced by grazing of cattle during the dry season. The fragment mentioned, although being isolated far from other similar fragments, has a historic of 60 years without human disturbance.

\subsection{Data sampling}

The floristic survey of vegetation was performed in 24 plots of equal size with $20 \times 20$ meters $\left(400 \mathrm{~m}^{2}\right)$. Plots were established on the edge $(n=12)$ and into the fragment $(n=12)$, in a systematic way at intervals of $141 \mathrm{~m}$. The edge plots were delimited so that the average distance from the centre of each plot to the edge of the fragment was $50 \mathrm{~m}$. For inner plots, the average distance of plot centre to the edge of the fragment was approximately $165 \mathrm{~m}$. These distances were enough to capture edge effects in this vegetation type among plots, because the major changes in vegetation occur within the first $50 \mathrm{~m}$ (LAURANCE et al., 1998, RIES et al., 2004, SANTOS; SANTOS 2008). The choice of plots rather than linear transects was adopted to allow comparison of results obtained in 
this study with a previous study that used the same methodology in Caatinga forest (Santos and Santos 2008).

In each plot all individuals tree with circumference at $1.30 \mathrm{~m}$ from ground level e $6.0 \mathrm{~cm}$ were identified and recorded, including the bifurcated individuals, according to the protocol established by "Rede de Manejo Florestal da Caatinga" (DANTAS et al., 2010). Total height (TH) of each individual was measured using a telescopic pole (marked by $10.60 \mathrm{~m}$ ). Individuals were tagged with numbered aluminium platelets. Samples were processed and identified according to standard methodology (Mori et al., 1989), being deposited in the herbarium of the Universidade Federal de Sergipe (ASE). The species were classified according to the Angiosperm Phylogeny Group system III (APGIII, 2009) and confirmation was done in the database of the Botanical Garden's VAST Missouri-MOBOT (www.mobot.mobot.org/W3T/search/ vast.html).

\subsection{Data analyzes}

The tree abundance, species richness and diversity index of Shannon-Wienner ( $\mathrm{H}^{\prime}$ ) were calculated using the "Mata Nativa 2.10 ${ }^{\circledR}$ " software (CALIXTO-JÚNIOR et al., 2011; TROVÃO et al., 2010). The influence of edge effects on canopy structure was analyzed using the leaf area index (LAI), through digital photos (10 megapixels) with hemispherical lens "fisheye" $\left(180^{\circ}\right)$. In the centre of each plot, three images were taken at a height of 1 meter from the ground, which were subsequently processed and analyzed in the Gap Light Analyzer software, version 2.0 (FRAZER et al., 1999). Differences between abundance, species richness, species diversity and LAI index (dependent variables) (independent variable) were tested in relation to the edge and interior plots using generalized linear models (GLM's). The models were subjected to residual analysis to verify their suitability for the error distribution used (normal, binomial or Poisson) (CRAWLEY, 2007). The GLM was performed using the software R (R Development Core Team, 2011).

The magnitude of the influence of edge effect was calculated according to the model proposed by Harper et al. (2005). In this model, the magnitude of edge influence is equal to: $(e-i) /(e+i)$, where $e=$ parameter value measured at the edge (i.e. abundance, species richness) and $\mathrm{i}=$ parameter value in the interior. The variation in magnitude is between -1 and 1 . Values equal to 0 indicates that there is no influence of edge. In addition, we evaluated the effect of distance from the edge of the variables examined (HARPER et al., 2005) using GLMs. We calculated the Pearson linear correlation (r) between variables and distance. Subsequently, the linearity of the correlation was tested using scatter plots (HAIR et al., 2009).

Non-metric multidimensional scaling (NMDS) analyses were carried out to verify differences between plots of the edge and interior. The ordination was conducted using the Jaccard Index (presence-absence). Additionally, similarity analyses (ANOSIM; CLARKE, 1993) were conducted to compare the difference between plot groups. Differences between R-values were used to determine similarity patterns between the communities of edge and interior sites. The analyses were conducted using the software PAST (HAMMER et al., 2001).

\section{RESULTS}

We sampled 2,534 individuals belonging to 49 wood species, distributed in 41 genera and 22 botanical families. Plots in the edge had 1,157 individuals and 43 species, while inner plots had 1,377 individuals and 42 species (Table 1). Of the 49 species sampled, $61 \%$ were arboreal, while $39 \%$ were shrubs.

Six species were exclusive of the interior habitat (Tabebuia aurea (Silva Manso) Benth. \& Hook. F., Eugenia ligustrina (Sw.) Willd., Psidium eugenioides (Cambess.) Nied, Capsicum parvifolium Sendtn., Solanum ovum-fringillae (Dunal) Bohs and Coutarea sp.), while seven species occurred only in the edge plots (Spondias tuberosa Arruda, Spondias sp., Cordia cf. insignis Cham., Cereus jamacaru DC., Pilosocereus piauhyensis (Gürke) Byles \& GD Rowley, Sapium glandulosum (L.) Morong and Handroanthus impetiginosus (Mart. ex DC. Mattos).

The NMDS ordination (stress $=0.2378$, Figure 2 ) and analysis of similarity (ANOSIM, R $=0.012, \mathrm{p}>$ 0.05 ) showed no differences in species composition between the two environments analyzed (edge and interior).

Also, the vegetation parameters analyzed (tree height, stem diameter, basal area, species richness, abundance and LAI index) did not result in statistically significant differences between areas (Table 2). 
Table 1 - List of woody species, with abundance values in 24 plots in the edge and interior for a Caatinga dry forest. Tabela 1 - Listagem das espécies lenhosas, com os valores de abundância nas 24 parcelas de borda e interior da floresta seca.

\begin{tabular}{|c|c|c|c|c|}
\hline \multirow{2}{*}{ Family/species } & \multirow{2}{*}{ Voucher } & \multirow{2}{*}{ Type } & \multicolumn{2}{|c|}{ Abundance } \\
\hline & & & Edge & Interior \\
\hline \multicolumn{5}{|l|}{ Anarcadiaceae } \\
\hline Myracrodruon urundeuva Allemão & 20367 & Tree & 30 & 43 \\
\hline Schinopsis brasiliensis Eng1. & 20368 & Tree & 10 & 2 \\
\hline Spondias mombin L. & - & Tree & 1 & 4 \\
\hline Spondias sp. & 20349 & Tree & 1 & 0 \\
\hline Spondias tuberosa Arruda & 20363 & Tree & 1 & 0 \\
\hline Apocynaceae & & & & \\
\hline $\begin{array}{l}\text { Aspidosperma pyrifolium Mart. } \\
\text { Bignoniaceae }\end{array}$ & 20364 & Tree & 43 & 48 \\
\hline Handroanthus impetiginosus (Mart. ex DC.) Mattos & - & Tree & 1 & 0 \\
\hline $\begin{array}{l}\text { Tabebuia aurea (Silva Manso) Benth. \& Hook. f. ex S. Moore } \\
\text { Boraginaceae }\end{array}$ & 20371 & Tree & 0 & 5 \\
\hline $\begin{array}{l}\text { Cordia } \text { cf. insignis Cham. } \\
\text { Burseraceae }\end{array}$ & - & Tree & 1 & 0 \\
\hline $\begin{array}{l}\text { Commiphora leptophloeos (Mart.) J.B. Gillett } \\
\text { Cactaceae }\end{array}$ & 20357 & Tree & 15 & 9 \\
\hline Cereus jamacaru DC. & - & Tree & 14 & 0 \\
\hline $\begin{array}{l}\text { Pilosocereus piauhyensis (Gürke) Byles \& G.D. Rowley } \\
\text { Capparaceae }\end{array}$ & 19296 & Shrub & 1 & 0 \\
\hline Cynophalla flexuosa (L.) J. Pres1 & 20352 & Shrub & 21 & 35 \\
\hline $\begin{array}{l}\text { Neocalyptrocalyx longifolium (Mart.) Cornejo \& Iltis } \\
\text { Celastraceae }\end{array}$ & 20365 & Shrub & 1 & 2 \\
\hline $\begin{array}{l}\text { Maytenus rigida } \text { Moric } \\
\text { Erythroxylaceae }\end{array}$ & 20369 & Shrub & 17 & 85 \\
\hline $\begin{array}{l}\text { Erythroxylum sp. nov. } \\
\text { Euphorbiaceae }\end{array}$ & 20580 & Shrub & 2 & 2 \\
\hline Croton adenocalix Baill. & 20355 & Shrub & 6 & 5 \\
\hline Croton sonderianus Müll. Arg. & 20384 & Shrub & 153 & 140 \\
\hline Jatropha molissima (Pohl) Baill. & 20347 & Shrub & 8 & 8 \\
\hline Mabea sp. & 20832 & Tree & 4 & 52 \\
\hline Manihot dichotoma Ule & 20346 & Shrub & 117 & 68 \\
\hline $\begin{array}{l}\text { Sapium glandulosum (L.) Morong } \\
\text { Fabaceae-Caesalpinioideae }\end{array}$ & 20358 & Tree & 3 & 0 \\
\hline Bauhinia cheilantha (Bong.) Steud. & 20375 & Tree & 438 & 529 \\
\hline $\begin{array}{l}\text { Poincianella pyramidalis (Tu1.) L.P. Queiroz } \\
\text { Fabaceae-Mimosoideae }\end{array}$ & 20350 & Tree & 88 & 107 \\
\hline Anadenanthera colubrina (Vell.) Brenan & 20361 & Tree & 61 & 82 \\
\hline Chloroleucon foliolosum (Benth.) G.P. Lewis & 21811 & Tree & 3 & 3 \\
\hline Piptadenia stipulacea (Benth.) Ducke & 20571 & Tree & 1 & 1 \\
\hline Piptadenia viridiflora (Kunth) Benth. & 20565 & Tree & 2 & 3 \\
\hline $\begin{array}{l}\text { Parapiptadenia zehntneri (Harms) M. P. M. de } \\
\text { Lima \& H. C. de Lima } \\
\text { Fabaceae-Faboideae }\end{array}$ & 20391 & Tree & 4 & 43 \\
\hline Amburana cearensis (Allemão) A.C. Sm. & - & Tree & 3 & 1 \\
\hline $\begin{array}{l}\text { Erythrina velutina Willd. } \\
\text { Malpighiaceae }\end{array}$ & 20390 & Tree & 1 & 1 \\
\hline $\begin{array}{l}\text { Ptilochaeta bahiensis Turcz. } \\
\text { Malvaceae }\end{array}$ & 21817 & Shrub & 1 & 2 \\
\hline
\end{tabular}


Table 1 - Cont...

Tabela 1 - Cont...

\begin{tabular}{|c|c|c|c|c|}
\hline \multirow{2}{*}{$\begin{array}{l}\text { Ceiba glaziovii (Kuntze) K. Schum. } \\
\text { Family/species }\end{array}$} & \multirow{2}{*}{$\begin{array}{l}20372 \\
\text { Voucher }\end{array}$} & \multirow{2}{*}{$\begin{array}{l}\text { Tree } \\
\text { Type }\end{array}$} & \multirow{2}{*}{\multicolumn{2}{|c|}{5 Abundance }} \\
\hline & & & & \\
\hline & & & Edge & Interior \\
\hline Helicteres sp. & 21819 & Shrub & 5 & 12 \\
\hline $\begin{array}{l}\text { Pseudobombax marginatum (A. St.-Hil., Juss. \& Cambess.) } \\
\text { A. Robyns }\end{array}$ & 21822 & Tree & 13 & 14 \\
\hline Meliaceae & & & & \\
\hline $\begin{array}{l}\text { Cedrela odorata L. } \\
\text { Myrtaceae }\end{array}$ & - & Tree & 4 & 2 \\
\hline Eugenia ligustrina (Sw.) Willd. & 20566 & Tree & 0 & 2 \\
\hline Eugenia punicifolia (Kunth.) DC. & 20828 & Shrub & 3 & 3 \\
\hline $\begin{array}{l}\text { Psidium eugenioides (Cambess.) Nied } \\
\text { Nyctaginaceae }\end{array}$ & 20827 & Shrub & 0 & 3 \\
\hline $\begin{array}{l}\text { Guapira tomentosa (Casar.) Lundell } \\
\text { Rhamnaceae }\end{array}$ & 20348 & Tree & 19 & 10 \\
\hline $\begin{array}{l}\text { Ziziphus joazeiro Mart. } \\
\text { Rubiaceae }\end{array}$ & 20356 & Tree & 21 & 5 \\
\hline Cordiera sp. & 20351 & Shrub & 8 & 2 \\
\hline Coutarea sp. & - & Shrub & 0 & 1 \\
\hline $\begin{array}{l}\text { Guettarda sericea Müll. Arg. } \\
\text { Salicaceae }\end{array}$ & 20354 & Shrub & 8 & 9 \\
\hline $\begin{array}{l}\text { Prockia crucis P. Browne ex L. } \\
\text { Sapindaceae }\end{array}$ & 20353 & Shrub & 3 & 2 \\
\hline $\begin{array}{l}\text { Allophylus quercifolius Mart. } \\
\text { Sapotaceae }\end{array}$ & 20345 & Shrub & 9 & 23 \\
\hline $\begin{array}{l}\text { Sideroxylon obtusifolium (Humb. ex Roem. \& Schult.) T.D. Penn. } \\
\text { Solanaceae }\end{array}$ & 20359 & Tree & 7 & 3 \\
\hline Capsicum parvifolium Sendtn. & 21059 & Shrub & 0 & 2 \\
\hline Solanum ovum-fringillae (Dunal) Bohs & 21820 & Shrub & 0 & 2 \\
\hline Total & & & 1157 & 1377 \\
\hline
\end{tabular}

\section{DISCUSSION}

The present study confirms the null hypothesis, that is, the edge effect does not affect the structure of plant communities in the Caatinga environment studied. These results corroborate previous studies (SAMPAIO; SCARIOT, 2011; Santos and Santos, 2008) suggesting that, unlike rainforests, the edge effect is not an important environmental variable in tropical dry forests (TDFs). Although some studies show that there is edge effect in semiarid environments (CASENAVE et al., 1995; CAVALCANTI; RODAL, 2010), our results support that the lack of edge effect is the pattern for this type of vegetation.

The species that were restricted only to the edge or interior plots accounted for only $1.46 \%$ of the total individuals sampled, and therefore do not allow inference about the existence of a restriction on the habitat preference for plants in edge or interior plots.

Revista Árvore, Viçosa-MG, v.37, n.2, p.311-320, 2013
In addition, the species in the forest fragment presented a random pattern of spatial distribution (Oliveira, unpublished data), indicating that their presence in each location can be examined associated with the dynamics of dispersion of seedlings (SANTANA, 2009).

The species composition between edge and interior plots was $73.4 \%$, with high floristic similarity. This result was similar to that found by Santos and Santos (2008) (77\% in floristic similarity), analyzing the occurrence of edge effect in a fragment of shrubby Caatinga in the state of Paraiba (about $500 \mathrm{~km}$ away from our site of study). Kent and Coker (1992) defined values greater than or equal to $50 \%$ as high in similarity between their sites.

According to Harper et al. (2005) in preserved environments, the forest edges tend to have a dominant structure more similar to its interior as a result of the restructuring of the impact over time. In semiarid 
ecosystems, however, this pattern can occur in fragments with recent historic of disturbances (CAVALCANTI; RODAL, 2010) but it is evident in an old Chaco semiarid forest (CASENAVE et al., 1995). These authors observed that edge effects were evident in the modification of the community structure, since basal area, plant species richness and abundance were significantly different between the edge and interior plots.

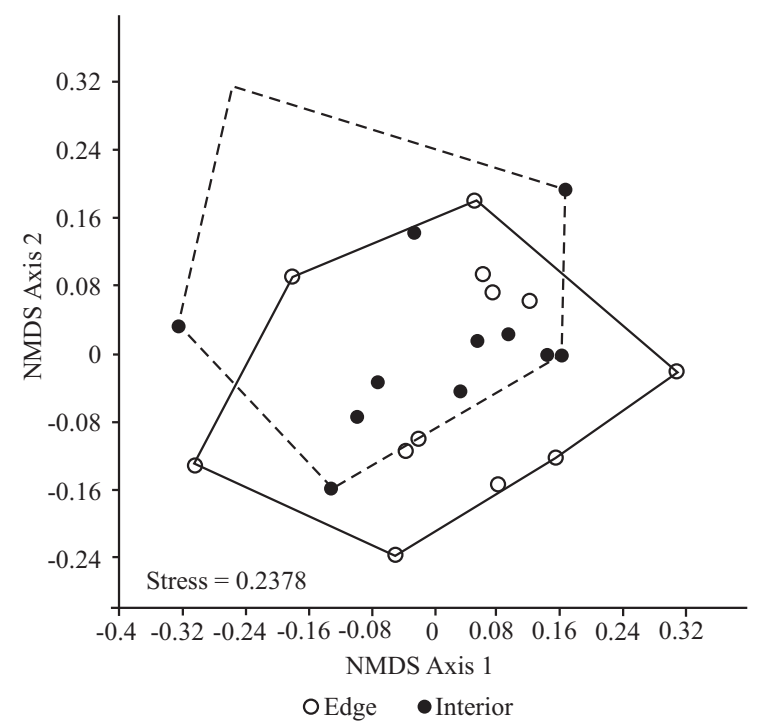

Figure 2 - Non-metric multidimensional scaling (NMDS) for ordination of wood species composition among plots of the edge $(0)$ and interior $(\bullet)$ of a Caatinga dry forest.

Figura 2 - Escalonamento multidimensional não-métrico (NMDS) para ordenação da composição de espécies entre as parcelas da borda (0) e do interior $(\bullet)$ da floresta seca.
Cavalcanti and Rodal (2010), evaluated the edge effect in three fragments of shrub Caatinga (open, dense and dense riparian) in the state of Rio Grande do Norte and although these authors have found slight differences between physiognomies studied, they concluded that, in general, there were no significant changes in any of physiognomic traits, either for trees or seedlings. Moreover, in a previous study, Santos and Santos (2008) observed that the community of shrubs was not affected by the creation of edges, suggesting that changes in physical conditions and the availability of resources after the creation of the edges are insufficient to eliminate established plants or change the recruitment and survival of new individuals. These authors also found values of magnitude close to zero, demonstrating the low ecological importance of edge creation for the variables analyzed in areas of Caatinga.

Similar results were found by testing the effect of edge distance on the structure of the plant community (adults, young and seedlings) in a deciduous dry forest in the northern state of Goiás (SAMPAIO; SCARIOT, 2011). In this case, only the diversity of seedlings and adult height was significantly different in relation to distance from the edge, showing a slight edge effect. However, the effect of distance on plant community has commonly been found in previous studies in other ecosystems (KAPOS, 1989; MATLACK, 1994; but see DIDHAN; LAWTON, 1999; MARCHAND; HOULE, 2006; MURCIA 1995).

Some structural patterns can help in understanding the absence of edge effect in the fragment studied. For example, LAI Index has direct relationship with the canopy cover during the change of season. The

Table 2 - Values of vegetation variables measured in the plots from the edge and the interior of a Caatinga dry forest. Table values are means \pm SE of 24 plots (12 for edge and 12 for interior).

Tabela 2 - Valores das variáveis de estrutura da vegetação mensuradas nas parcelas a partir da borda e no interior de uma floresta seca. Os valores da tabela são médias \pm EP de 24 parcelas (12 de borda e 12 para o interior).

\begin{tabular}{|c|c|c|c|c|c|}
\hline \multirow{2}{*}{ Parameter } & \multicolumn{2}{|c|}{ Value } & \multirow{2}{*}{ Magnitude } & \multirow{2}{*}{ Test-value } & \multirow{2}{*}{ p-value } \\
\hline & Edge plots & Interior plots & & & \\
\hline Total height (m) & $5.9 \pm 0.059$ & $5.93 \pm 0.055$ & 0 & $X^{2}=1621$ & 0.77 \\
\hline Stem diameter $(\mathrm{cm})$ & $5.67 \pm 0.141$ & $5.66 \pm 0.13$ & 0 & $X^{2}=6943$ & 0.94 \\
\hline Basal area & $15.17 \pm 0.04$ & $15.71 \pm 0.05$ & -0.017 & $X^{2}=20367$ & 0.75 \\
\hline Abundance & $96.42 \pm 6.35$ & $114.75 \pm 11.6$ & -0.087 & $F=1.923$ & 0.179 \\
\hline Species richness & $13.75 \pm 1.25$ & $13.77 \pm 1.47$ & -0.001 & $F=0.046$ & 0.83 \\
\hline Species diversity ( $\left.\mathrm{H}^{\prime}\right)$ & $2.39 \pm 0.111$ & $2.37 \pm 0.10$ & 0.004 & $F=1.43$ & 0.24 \\
\hline LAI Index & $0.65 \pm 0.09$ & $0.73 \pm 0.08$ & -0.058 & $F=0.478$ & 0.49 \\
\hline
\end{tabular}


canopy of tropical dry forests are more opened when compared to the tropical rainforests, and leaf fall during the dry season lead to low LAI values in these habitats (SAMPAIO; SCARIOT, 2011). Thus, the influence of the edge is less pronounced and difficult to detect in forests with a more opened canopy (HARPER et al., 2005). Consequently, a less contrasting microclimatic gradient is expected in the edge plots in dry forests than in rainforests, affecting the organisms to a lesser extent (SAMPAIO; SCARIOT, 2011).

The physiognomic and structural similarity of vegetation in different plots (edge and interior) of the studied area, suggest the existence of a common pattern, possibly related to the homogeneous availability of resources (such as light, water and nutrients) and regeneration time. On the other hand, if the environmental factors are not similar between edge and inner plots, it is likely that changes in physical conditions and the availability of resources after the creation of edges are insufficient to eliminate established plants or alter the survival and development of new individuals.

The results presented in this study contradict several studies made in tropical rain forests (LAURANCE et al., 1998; LIMA-RIBEIRO, 2008; NASCIMENTO; LAURANCE, 2006; PACIENCIA; PRADO, 2004). Those authors have found lower richness, diversity and abundance of species at the edges than forest interior, but corroborates other studies done in dry forests that demonstrate the absence of edge effect in these environments (CAVALCANTI; RODAL, 2010; SAMPAIO; SCARIOT, 2011; SANTOS; SANTOS, 2008). Thus, further studies in semiarid environments, such as Caatinga, may increase our knowledge on the response of plant communities to the edge effect. Apparently, so far, the edge effect does not influence the plant community structure in areas of Caatinga.

\section{CONCLUSION}

This study contributes to the knowledge about the effects of fragmentation in dry forests (mainly within the Caatinga) adding further evidence to the fact that there are vegetation types and conditions under which the edge effects can be considered negligible in the context of plant communities. This knowledge may contribute to the success of programs of regeneration of degraded areas or for the conservation of wood species threatened in a fragmented landscape.

Revista Árvore, Viçosa-MG, v.37, n.2, p.311-320, 2013

\section{ACKNOWLEDGEMENTS}

We would like to thank Coordenação de Aperfeiçoamento de Pessoal de Nível Superior (CAPES, Brazil), for the financial support; Anderson Santos for the logistical support and Paulo Chave for permission to perform this research on São Pedro farm. We also thank Mr. Dedé for his help with the species recognition in the field and we thank the people of São Judas Tadeu for their hospitality, especially to Ms. Branca.

\section{REFERENCES}

ANDRADE-LIMA, D. The caatingas dominium. Revista Brasileira de Botânica, v.4, n.2, p.149-153, 1981.

APG III. An update of the Angiosperm Phylogeny Group Classification for the Orders and Families of Flowering Plants: APG III. Botanical Journal of the Linnean Society, v.161, n.2, p.105-121, 2009.

CALIXTO-JÚNIOR, J. T.; DRUMOND, M. A.; ALVES-JÚNIOR, F. T. Estrutura e distribuição espacial de Mimosa tenuiflora (Willd.) Poir. em dois fragmentos de Caatinga em Pernambuco. Revista Caatinga, v.24, n.1, p.95-100, 2011.

CAMARGO, J. L. C.; KAPOS, V. Complex edge effects on soil moisture and microclimate in central Amazonian forest. Journal of Tropical Ecology, v.11, p.205-221, 1995.

CASENAVE, J. L.; PELLOTO, J. P.;

PROTOMASTRO, J. Edge-interior differences in vegetation structure and composition in a Chaco semi-arid forest, Argentina. Forest Ecology and Management, v.72, n.1, p.61-69, 1995.

CAVALCANTI, A. D. C.; RODAL, M. J. N. Efeito de borda e dinâmica de plantas lenhosas em áreas de Caatinga em Carnaubais, RN. Revista Caatinga, v.23, n.1, p.41-50, 2010.

CLARKE, K. R. Non-parametric multivariate analysis of changes in community structure. Australian Journal of Ecology, v.18, n.1, p.117-143, 1993.

CRAWLEY, M. J. The R book. New York: Wiley, 2007. 
DANTAS, J. G. et al. Estrutura do componente arbustivo/arbóreo de uma área de Caatinga situada no município de Pombal-PB. Revista Verde, v.5, n.1, p.134-142, 2010.

DIDHAM, R. K.; LAWTON, J. H. Edge structure determines the magnitude of changes in microclimate and vegetation structure in tropical forest fragments. Biotropica, v.31, n.1, p.17-30, 1999.

EMPRESA BRASILEIRA DE PESQUISA AGROPECUÁRIA - EMPBRAPA. Sistema brasileiro de classificação de solos. 2.ed. Brasília: Embrapa Produção de Informação; Rio de Janeiro: Embrapa Solos, 2006. 306p.

FAHRIG, L. Effects of habitat fragmentation on biodiversity. Annual Reviews of Ecology and Systematics, v.34, p.487-515, 2003.

FRAZER, G. W.; CANHAM, C. D.; LERTZMAN, K. P. Gap Light Analyzer (GLA): imaging software to extract canopy structure and gap light transmission indices from true-colour fisheye photographs, users manual and program documentation. Version 2.0, New York: Millbrook, 1999.

HAIR, J. F. et al. Análise multivariada de dados. 6.ed. Porto Alegre: Bookman, 2009. 688p

HAMMER, O.; HARPER, D. A. T.; RYAN, P. D. PAST: Palaeonthological Statistics Software Package for education and data analysis. Palaeontologia Electronica, v.4, n.1, p.1-9, 2001.

HARPER, K. A. et al. Edge influence on forest structure and composition in fragmented landscapes. Conservation Biology, v.19, n.3, p.768-782, 2005.

KAPOS, V. Effects of isolation on the water status of forest patches in the Brazilian Amazon.

Journal of Tropical Ecology, v.5, n.2, p.173-185, 1989.

KENT, M.; COKER, P. Vegetation description analyses. London: Behaven Press, 1992. 363p.

LAURANCE, W. F. et al. Rain forest fragmentation and the dynamics of Amazonian tree communities. Ecology, v.79, n.6, p.2032-2040, 1998.
LAURANCE, W. F. et al. Rain forest fragmentation and the structure of Amazonian liana communities. Ecology, v.82, n.1, p.105116,2001

LIMA-RIBEIRO, M. S. Efeitos de borda sobre a vegetação e estruturação populacional em fragmentos de Cerradão no Sudoeste Goiano, Brasil. Acta Botanica Brasilica, v.22, n.2, p.535-545, 2008.

MARCHAND, P.; HOULE, G. Spatial patterns of plant species richness along a forest edge: What are their determinants? Forest Ecology and Management, v.223, p.113-124, 2006.

MATLACK, G. R. Vegetation dynamics of the forest edge - trends in space and sucessional time. Journal of Ecology, v.82, n.1, p.113$123,1994$.

MESQUITA, R. C. G.; DELAMONICA, P.; LAURANCE, W. F. Effect of surrounding vegetation on edge-related tree mortality in Amazonian forest fragments. Biological Conservation, v.91, n.1, p.129-134, 1999.

MORI, S. et al. Manual de manejo do herbário fanerogâmico. Ilhéus: Ceplac, 1989. 104p.

MURCIA, C. Edge effects in fragmented forests: implications for conservation. Trends in Ecology and Evolution, v.10, n.1, p.58-62, 1995.

NASCIMENTO, H. E. M.; LAURANCE, W. F. Area and edge effects on forest structure in Amazonian forest fragments after 13-17 years of isolation. Acta Amazonica, v.36, n.2, p.183$192,2006$.

PACIENCIA, M. L. B.; PRADO, J. Efeitos de borda sobre a comunidade de pteridófitas na Mata Atlântica da região de Una, sul da Bahia, Brasil. Revista Brasileira de Botânica, v.27, n.4, p.641-653, 2004

PENNINGTON, R. T.; PRADO, D. E.; PENDRY, C. A. Neotropical seasonally dry forests and quaternary vegetation changes. Journal of Biogeography, v.27, n.2, p.261-273, 2000.

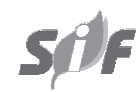

Revista Árvore, Viçosa-MG, v.37, n.2, p.311-320,, 2013 
R DEVELOPMENT CORE TEAM, 2011. R: A language and environment for statistical computing. R Foundation for Statistical Computing, Vienna. Disponível em: < http:// www.R-project.orgS.>. Acesso em 20 de jul. de 2012.

RIES, L. et al. Ecological responses to habitat edges: mechanisms, models, and variability explained. Annual Review of Ecology, Evolution and Systematic, v.35, p.491-522, 2004.

SAMPAIO, E. V. S. B. Overview of the Brazilian Caatinga, in: BULLOCK, S. H.; MOONEY, H. A.; MEDINA, E. (Ed.) Seasonal dry tropical forests., London: Cambridge University Press, 1995. p.35-63.

SAMPAIO, A. B.; SCARIOT, A. Edge effect on tree diversity, composition and structure in a deciduous dry forest in Central Brazil. Revista Árvore, v.35, n.5, p.1121-1134, 2011.

SANTANA, J. A. S. Padrão de distribuição e estrutura diamétrica de Croton sonderianus Müll. Arg. (Marmeleiro) na caatinga da Estação Ecológica do Seridó. Revista Verde de Agroecologia e Desenvolvimento Sustentável, v.4, n.1, p.85-90, 2009.
SANTOS, A. M. M.; SANTOS, B. A. Are the vegetation structure and composition of the shrubby Caatinga free from edge influence? Acta Botanica Brasilica, v.22, n.4, p.1077-1084, 2008.

SANTOS, B. A. et al. Drastic erosion in functional attributes of tree assemblages in Atlantic forest fragments of northeastern Brazil. Biological Conservation, v.141, n.1, p.249-260, 2008.

SILVA, I. A. A.; PEREIRA, A. F. N.; BARROS, I. C. L. Edge effects on fern community in an Atlantic Forest remnant of Rio Formoso, PE, Brazil.

Brazilian Journal of Biology, v.71, p.221230, 2011.

TABARELLI, M.; MANTOVANI, W.; PERES, C. A. Effects of habitat fragmentation on plant guild structure in the montane Atlantic forest of southeastern Brazil. Biological

Conservation, v.91, n.1, p.119-127, 1999.

TROVÃO, D. M. B. M.; FREIRE, A. M.; MELO, J. I. M. Florística e fitossociologia do componente lenhoso da mata ciliar do riacho de Bodocongó, Semiárido Paraibano. Revista Caatinga, v.23, n.1, p.78-86, 2010.

TILMAN, D. et al. Habitat destruction and the extinction debt. Nature, v.371, p.65-66, 1994. 